\title{
MINERAL RESOURCE POTENTIAL OF MOSES AND DENNISON PEAK ROADLESS AREAS, TULARE COUNTY, CALTFORNIA
}

\author{
By \\ Richard J. Goldfarb, David L. Leach, and Michael G. Sawlan, U.S. Geological Survey \\ and \\ D. A. Lipton, U.S. Burean of Mines
}

\section{STUDIES RELATED TO WILDERNESS}

Under the provisions of the Wilderness Act (Public Law 88-577, September 3, 1964) and related acts, the U.S. Geological Survey and the U.S. Bureau of Mines have been conducting mineral surveys of wilderness and primitive areas. Areas officially designated as "wilderness," "wild," or "canoe" when the act was passed were incorporated into the National Wilderness Preservation System, and some of them are presently being studied. The act provided that areas under consideration for wilderness designation should be studied for suitability for incorporation into the Wilderness System. The mineral surveys constitute one aspect of the suitability studies. The act directs that the results of such surveys are to be made available to the public and be submitted to the President and the Congress. This report discusses the results of mineral surveys of Moses (05203) and Dennison Peak (05202) Roadless Areas, Sequoia National Forest, Tulare County, California. The areas were classified as further planning areas during the Second Roadless Area Review and Evaluation (RARE II) by the U.S. Forest Service, January 1979.

\section{MINERAL RESOURCE POTENTIAL SUMMARY STATEMENT}

Five localities within the Moses and Dennison Peak Roadless Areas were defined as having moderate to high potential for small lead-silver-zinc-, copper-, and tungsten-bearing skarns. Anomalous stream-sediment and heavy-mineral concentrate data, favorable host lithology, and examination of known mines and prospects were used to define the five areas of favorability.

\section{INTRODUCTION}

\section{Location of study area}

The Moses and Dennison Peak Roadless Areas occupy $36 \mathrm{mi}^{2}$ and $9 \mathrm{mi}^{2}$, respectively, in the southern Sierra Nevada of California, southeast of Sequoia National Park (fig. 1). Both areas are contained totally within lands administered by Sequoia National Forest. They include at least a part of the Camp Nelson, Mineral King, and Kaweah 15-minute quadrangle maps, and the Springville 7.5-minute quadrangle map. Springville lies $4 \mathrm{mi}$ to the southwest and Visalia is $30 \mathrm{mi}$ to the northwest. California Highway 190 and Balch Park Road are the principal access routes.

Both roadless areas are characterized by extreme relief and covered by dense manzanita and conifer forests. The Dennison Peak Roadless Area ranges in elevation from 3,600 to $8,400 \mathrm{ft}$ near Dennison Mountain. The North Fork of the Tule River and the Dillonwood Grove property separating the Dennison Peak Roadless Area from the Moses Roadless Area range in elevation from 3,700 ft along the North Fork of the Tule River to 9,300 ft at Moses Mountain. The Moses Roadless Area is bisected by the Mountain Home State Forest.

\section{GEOLOGY}

A detailed discussion of the geology of Moses and Dennison Peak Roadless Areas is given by Sawlan and Ort (in press). A brief summary is presented below.

The geology of the roadless areas consists of the $16-\mathrm{mi}^{2}$ Upper Triassic(?) to Middle Jurassic(?) WishonTule pendant of metasedimentary and metavolcanic rocks that was intruded by plutons of granitic to gabbroic composition. Relict bedding in the pendant consistently strikes approximately N. $20^{\circ}$ W. and dips subvertically. The generally consistent bedding attitudes and sparse but excellently preserved geopetal indicators suggest that the roof pendant is a homocline. The pendant is appraximately $2 \mathrm{mi}$ thick (all thickness estimates refer to structural thicknesses) and consists of dominantly quartzose metasediments that are overlain by up to $0.8 \mathrm{mi}$ of metavolcanic rocks. The local presence of transposed bedding adds some internal complexity to the stratigraphy but apparently does not affect the fundamental stratigraphic sequence.

The base of the Wishon-Tule pendant is composed of continentally-derived, predominantly quartzose metasediments with minor pods of marble and calcsilicate rocks. The metasediments are cut by 
metamorphosed mafic dikes and sills, and small felsic plugs.

Metavolcanic rocks crop out along the eastern margin of the Wishon-Tule pendant. Exposures of this unit are largely of blastoporphyritic lavas. Whole rock major element geochemical analyses of 12 samples (M. G. Sawlan, unpub. data, 1983), relict phenocryst phases, and present groundmass mineralogy indicate that rock compositions range from basalt to rhyolite. Most of the metavolcanic rocks appear massive in outcrop. Some lavas are brecciated but mesoscopic volcanic structures that discriminate between subaerial and subaqueous modes of eruption were not seen in traverses.

The precise nature of the contact between the metasedimentary and metavolcanic units is uncertain. However, Sawlan and Ort (in press) believe that the contact is fairly sharp and occurs within a covered interval only several feet wide. There is no evidence of tectonic interleaving of metasediments and metavolcanic rocks along the contact and no metasedimentary beds were observed in the more than 4,000-ft thick section of metavolcanic rocks.

The Wishon-Tule pendant underwent postdepositional events that included tilting, middle to upper greenschist grade dynamothermal metamorphism, and thermal metamorphism. Deformation and regional metamorphism (middle to upper greenschist facies) preceded thermal metamorphic events that coincided with emplacement of the plutons. The sequence of metamorphism in this area parallels that observed at Mineral King by Christensen (1963).

Twelve intrusive units were identified by Sawlan and Ort (in press) within the roadless areas. These plutons include alaskitic granite, two-mica granite, granodiorite, quartz diorite, diorite, and gabbro. Contacts between plutons are generally sharp but in some plutons agmatitic zones are present. Internal structures vary greatly in character and intensity within each pluton.

The plutons vary in size by several orders of magnitude. The granodiorite of Mountain Home and the alaskite of Moses Mountain comprise more than 90 percent of the plutonic rocks in the mapped area. In contrast, the dioritic and gabbroic plutons occur in discrete bodies with areas of only approximately $0.05-$ $0.2 \mathrm{mi}^{2}$. Larger dioritic plutons are present south of the study area, however. Reconnaissance mapping outside the roadless areas indicates that these gabbroic and dioritic plutons represent the apophyses of a larger, mostly dioritic complex to the south.

The roadless areas were not subject to Pleistocene glaciation. With the exception of alluvial deposits and the inferred late Cenozoic uplift and unroofing of the batholith, only the Mesozoic history of this region is represented.

\section{GEOCHEMISTRY}

A reconnaissance geochemical survey using stream-sediment and heavy-mineral concentrate samples was conducted within the Moses and Dennison Peak Roadless Areas. Sediment and concentrate samples from 85 sites were analyzed semiquantitatively for 31 elements using an optical emission spectrograph. Geochemical thresholds were selected for elements known to occur in minerals associated with types of deposits found within, or near to, the roadless areas. Methodology for selection of these thresholds is discussed in Goldfarb and others (1984).
Four geochemically anomalous regions were identified: (1) anomalous boron and zinc in stream sediments, and boron, silver, and bismuth in heavymineral concentrates were found in the area underlain by the roof pendant centered around the North Fork of the Middle Fork of the Tule River; (2) stream-sediment samples from Kramer Creek and vicinity, within the western portion of the Dennison Peak Roadless Area, had anomalously high concentrations of lead and silver. Corresponding heavy-mineral concentrates had above background values for boron, tin, lead, silver, arsenic, and gold; (3) concentrate samples between Backbone and Pine Creeks were found to contain anomalous tungsten and bismuth; and (4) tin, lead, and molybdenum were enriched in sediment samples just to the west of Moses Mountain. Corresponding concentrate samples lacked anomalous element concentrations. Therefore, this suite of elements might just be representative of the highly differentiated alaskite that underlies this area.

\section{MINERAL OCCURRENCES}

Figure 2 shows the known mineral occurrences within and adjacent to the roadless areas. Minor skarn mineralization is associated with the contacts between the plutons and metamorphic pendant rocks. Veins containing pyrrhotite, chalcopyrite, argentiferous galena, and sphalerite occur in the Camp Wishon district, located within the Moses Roadless Area to the east of the North Fork of the Miadle Fork of the Tule River. These occurrences are reported to contain scheelite and minor gold (California Division of Mines, 1930). Additional known mineralization is reported from the Royal Tungsten, Martin, and Good Hope Mines, 2 mi northwest of Dennison Peak Roadless Area. Scheelite in this area is associated with garnet and epidote along contacts between the granitic rocks and lime-rich metamorphic rocks (Krauskopf, 1953).

Very little production has been recorded from these occurrences. Less than $10,000 \mathrm{lbs}$ of copper were taken from the Camp Wishon district. A small shipment of ore from the Cedar Hill claim had a smelter recovery of $81 \mathrm{oz} / \mathrm{ton}$ of silver (Goodwin, 1958). The combined production and reserves of the Good Hope, Martin, and Royal Tungsten mines is estimated to be less than 100 short tons of tungsten (Krauskopf, 1953).

\section{ASSESSMENT OF MINERAL RESOURCE POTENTIAL}

Areas have been identified as having high, moderate, or low resource potential for indicated commodities are based on the following criteria:

High resource potential: Anomalous concentrations of ore-related elements in samples of stream sediment and nonmagnetic heavy-mineral concentrate in areas containing favorable host rocks and known mineral resources or occurrences.

Moderate resource potential: Anomalous concentrations of ore-related elements in samples of stream sediment and (or) nonmagnetic heavymineral concentrate; or the presence of favorable host rocks, without anomalous concentrations of ore-related elements.

Low resource potential: Geologic and geochemical data indicate the existence or resources is unlikely and no known mines or prospects present. 
Because our sample sites are widely spaced with respect to the size of potential ore occurrences in the geological environment, the levels of favorability are broad and the boundaries of favorable terrain are hiphly generalized.

Mineralization of possible significance within the two roadless areas probably represents small occurrences of tungsten-, copper-, or zinc-bearing skarns. Five areas (fig. 2) were identified to have moderate or high mineral resource potential:

Area I-High resource potential for $\mathrm{Zn}-\mathrm{Pb}-\mathrm{Ag}$-bearing skarn and moderate resource potential for Cu-bearing skarn.

Area II-Moderate resource potential for W-bearing skarn or weakly mineralized alaskite.

Area III-Moderate resource potential for $\mathrm{Zn}-\mathrm{Pb}-\mathrm{Ag}-$ bearing skarn.

Area IV-Moderate resource potential for base-metal or W-bearing skarn mineralization.

Area V-Moderate resource potential for base-metalor W-bearing skarn mineralization.

\section{Area I}

Area $I$ is along and east of the North Fork of the Middle Fork of the Tule River; it is underlain by the largest exposure of metamorphic roof pendant within the Moses and Dennison Peak Roadless Areas. Calcareous rock in this area was probably altered by hydrothermal fluids, originating from adjacent plutons, to form calc-silicate minerals and associated ore mineral assemblages. Mines and prospects 1 through 15 (fig. 2) occur within or along the periphery of area $I$, and define what is locally referred to as the Camp Wishon district. Prospects 1, 2, and 5 are predominantly copper rich; the other 12 occurrences were prospected for zinc-lead-silver. The majority of the sulfide minerals are located in quartz veins or epidote-rich zones within calcareous layers adjacent to granodiorite. The sulfides include pyrrhotite, chalcopyrite, argentiferous galena, and sphalerite, occasionally associated with scheelite or minor gold (California Division of Mines, 1930). The chief gangue minerals are garnet, epidote, hornblende, actinolite, feldspar, calcite, and quartz.

The area is characterized geochemically by anomalous boron and zinc in samples of stream sediment, as well as by high concentrations of boron, silver, and bismuth in samples of nonmagnetic heavy minerals (Goldfarb and others, 1984). No copper enrichment was observed in either sample type. Because anomalous amounts of copper were not detected in the geochemical samples, area I was considered to have only moderate potential for copperbearing skarn deposits. It has high potential for small zinc-lead-silver-bearing skarn deposits.

\section{Area II}

Area II, underlain by the Alaskite of Moses Mountain, contains no known mineral prospects. However, nonmagnetic heavy-mineral concentrate samples from this area are anomalous in tungsten and bismuth. These anomalies could be derived from two possible sources.

Tungsten mines are located in metamorphic rocks both east (Pine Tree mine) and west (Good Hope, Royal Tungsten, and Martin mines) of the roadless areas. No metamorphic septa could be identified during detailed geologic mapping in area II; however, Goldfarb and Leach feel that small scheelite deposits could exist along contacts between the alaskite and the unexposed calcareous metasediments.

Sawlan has proposed an alternative hypothesis to explain the geochemical anomalies. Ferruginousstained alaskite from a 30 -foot-wide alteration zone along Balch Park Road near Pine Creek contains disseminated sulfides (Sawlan and Ort, in press). An iron-stained zone was also found approximately $0.4 \mathrm{mi}$ west of Moses Mountain, within the border of area II. Thus, Sawlan feels that the tungsten and bismuth enrichments may have been derived from areas of hydrothermal alteration within the alaskite.

Area II is considered to have moderate resource potential for weakly mineralized granite or small tungsten-bearing skarn occurrences.

\section{Area III}

Area III, underlain by a cataclastically deformed granodiorite, is geochemically anomalous in several elements. Stream sediments are enriched in lead and silver, and concentrates show anomalous amounts of boron, tin, lead, silver, gold, and arsenic. No mines or prospects are known within this area although it lies within $2 \mathrm{mi}$ of known metasomatic scheelite deposits (fig. 2, occurrences 16-18). This area has been assigned moderate potential for small zinc-lead-silverbearing skarn occurrences.

\section{Areas IV and V}

Areas IV and V do not contain geochemical anomalies. However, they are additional areas underlain by metamorphic rocks that possibly could host base-metal or scheelite mineralization within contact zones. Thus, these areas are considered to have a moderate resource potential for small skarntype mineral deposits.

\section{REFERENCES CITED}

California Division of Mines, 1930, Chapter of report XXVI of the State mineralogist: California Journal of Mines and Geology, v. 26, no. 1, p. 467.

Christensen, M. N., 1963, Structure of metamorphic rocks at Mineral King, California: California University Publications in Geological Sciences, v. 42, no. 4, p. 159-198.

Goldfarb, R. J., Leach, D. L., Domenico, J. A., and Smaglik, S. M., 1984, Geochemical map of the Moses and Dennison Peak Roadless Areas, California: U.S. Geological Survey Miscellaneous Field Studies Map MF-1651-B, scale 1848,000.

Goodwin, J. G., 1958, Mines and mineral resources of Tulare County, California: California Journal of Mines and Geology, v. 54, no. 3, p. 317-492.

Krauskopf, K. B., 1953, Tungsten deposits of Madera, Fresno, and Tulare Counties, California: California Division of Mines Special Rej srt 35, $83 \mathrm{p}$.

Sawlan, M. G., and Ort, K. M., in press, Geologic map of the Moses and Dennison Peak Roadless Areas, Tulare County, California: U.S. Geological Survey Miscellaneous Field Studies Map MF1651-C, scale 1:48,000. 


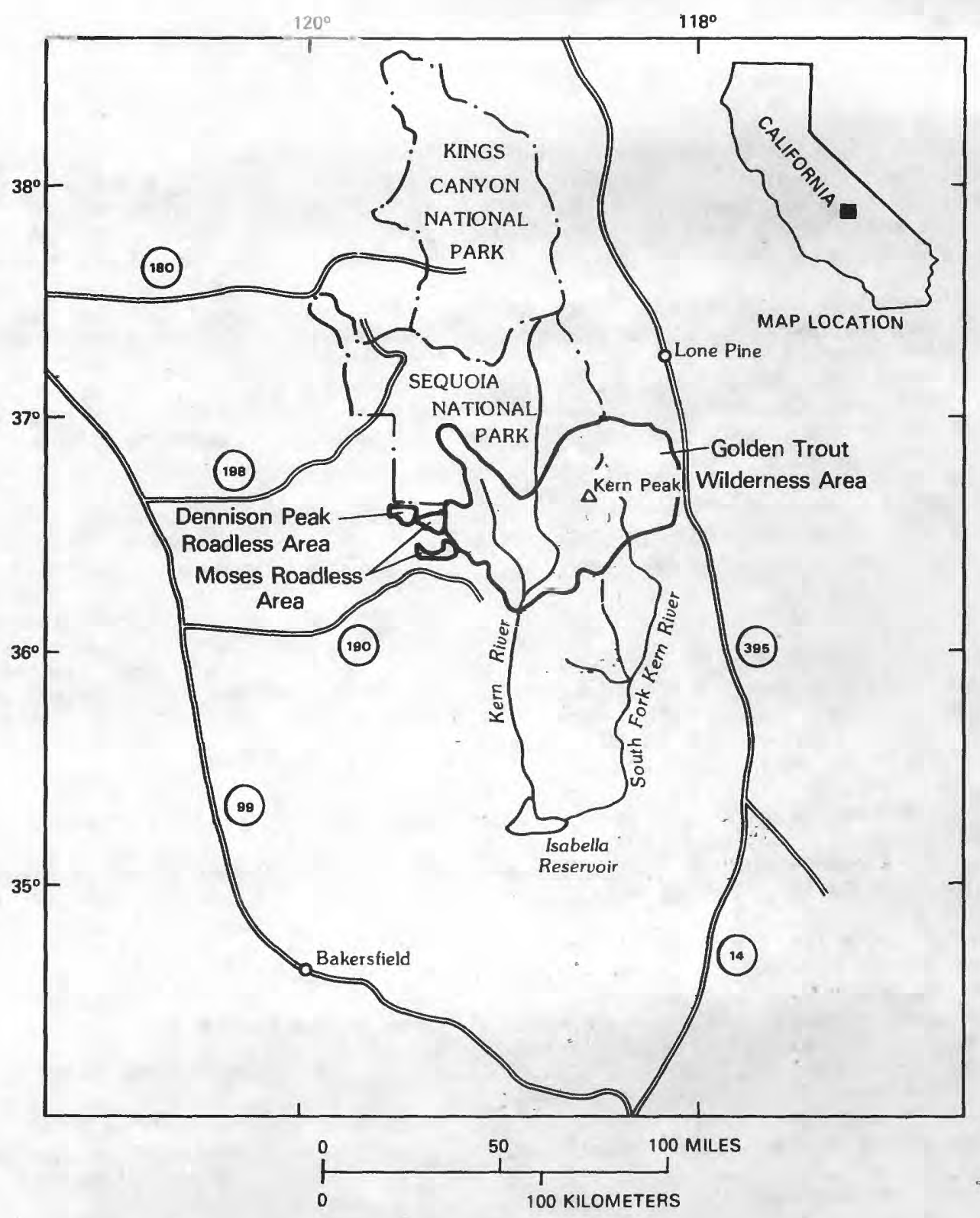

Figure 1.-Index map showing location of Moses and Dennison Peak Roadless Areas, Tulare County, California. 


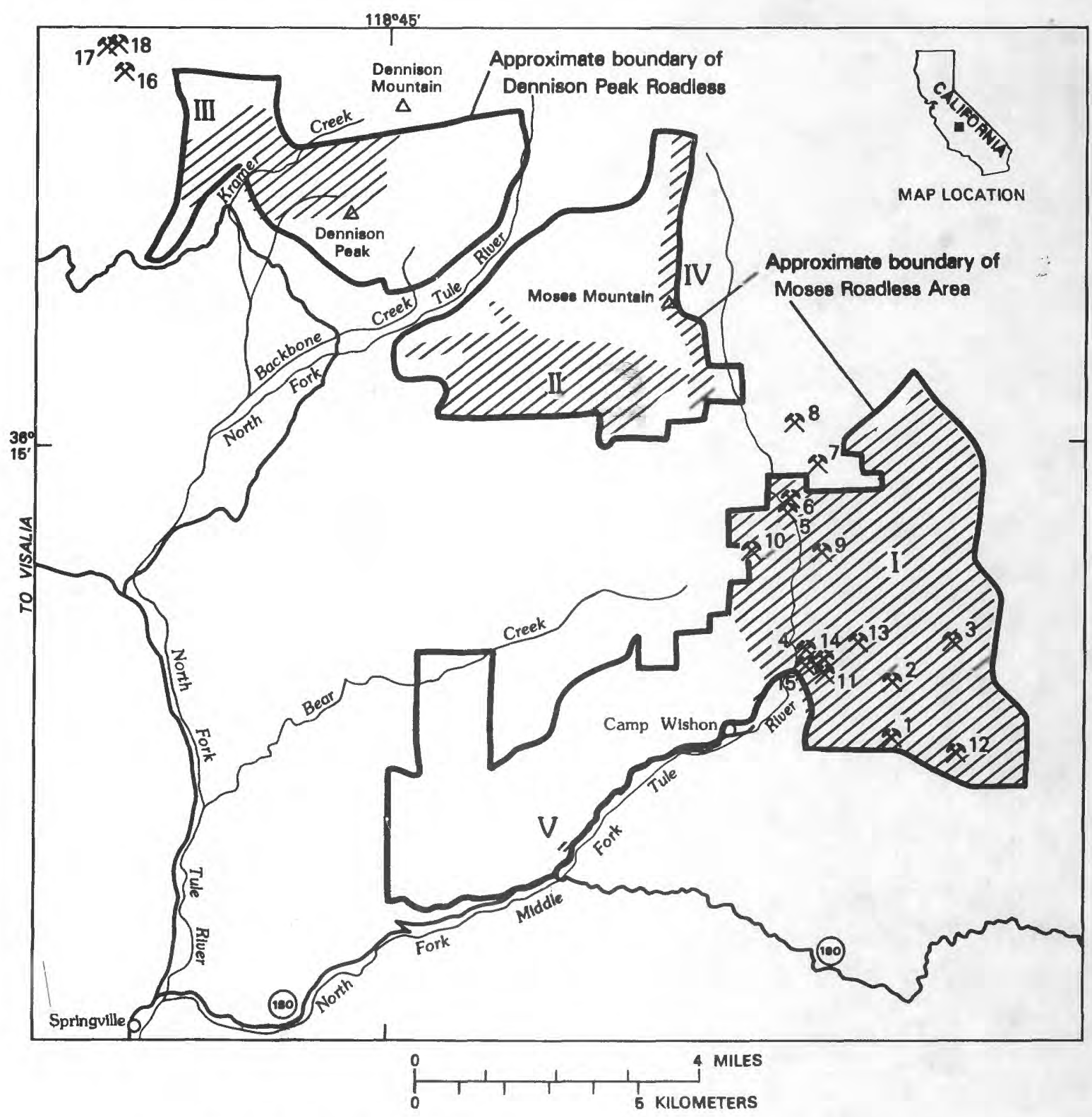

\begin{tabular}{|c|c|c|}
\hline \multicolumn{3}{|c|}{ Mineral resource potential } \\
\hline Area ${ }^{1}$ & $\begin{array}{l}\text { Resource } \\
\text { potential }\end{array}$ & Commodities \\
\hline I & High........ & $\begin{array}{c}\mathrm{Pb}-\mathrm{Ag}-\mathrm{Zn}-\text { and } \mathrm{Cu}- \\
\text { bearing charn. }\end{array}$ \\
\hline II & Moderate... & $\begin{array}{l}\text { W-bearing akarn } \\
\text { or weakly } \\
\text { mineralied } \\
\text { alakite. }\end{array}$ \\
\hline III & Moderate ... & $\begin{array}{l}\mathrm{Pb}-\mathrm{Ag}_{\mathrm{g}} \mathrm{Zn} \text {-bearing } \\
\text { skarn. }\end{array}$ \\
\hline IV & Moderate ... & $\begin{array}{l}\mathrm{Pb}-\mathrm{Ag}-\mathrm{Zn}-, \mathrm{Cu}-\text {, } \\
\text { and(or) } \mathrm{w}- \\
\text { bearing akarn. }\end{array}$ \\
\hline $\mathbf{V}$ & Moderate ... & $\begin{array}{l}\mathrm{Pb}-\mathrm{Ag}-\mathrm{Zn}-, \mathrm{Cu}-, \\
\text { and(or) } \mathrm{W}- \\
\text { bearing akarn. }\end{array}$ \\
\hline
\end{tabular}

\begin{tabular}{|c|c|c|}
\hline \multicolumn{3}{|c|}{ Mines and prospects } \\
\hline $\begin{array}{l}\text { Map } \\
\text { No. }\end{array}$ & Name & Commodities \\
\hline 1 & Iron Capping...... & $\mathrm{Cu}(\mathrm{Pb}, \mathrm{Zn})$ \\
\hline 2 & Barber-Witt ...... & $\mathrm{Cu}$ \\
\hline 3 & Prince Albert ..... & $\mathrm{Zn}-\mathrm{Pb}-\mathrm{A}_{\mathbf{g}}$ \\
\hline 4 & $\begin{array}{l}\text { Thunder Shower } \\
\text { and Buckhead... }\end{array}$ & $\mathrm{Zn}-\mathrm{Pb}-\mathrm{Ag}_{\mathrm{g}}$ \\
\hline 5 & Powell ............ & $\mathrm{Cu}(\mathrm{Pb}, \mathrm{Zn}, \mathrm{W})$ \\
\hline 6 & Cedar Hill......... & $\mathrm{Zn}-\mathrm{Pb}-\mathrm{Ag}_{\mathrm{g}}$ \\
\hline 7 & Galena Cave...... & $\mathrm{Zn}-\mathrm{Pb}-\mathrm{Ag}$ \\
\hline 8 & Skylark .......... & $\mathrm{Zn}-\mathrm{Pb}-\mathrm{Ag}$ \\
\hline 9 & Dewey........... & $\mathrm{Cu}$ \\
\hline 10 & Grider........... & $\mathrm{Cu}$ \\
\hline 11 & Arsenic and & \\
\hline & Soda Springs .... & $\mathrm{Zn}-\mathrm{Pb}$ \\
\hline 12 & Elder-Berry ....... & $\mathbf{P b}-\mathbf{Z n}$ \\
\hline 13 & Meadows Group ... & $\mathrm{Zn}-\mathrm{Pb}$ \\
\hline 14 & Monarch Group ... & $\mathrm{Zn}-\mathrm{Pb}$ \\
\hline 15 & Peach Dumpling & \\
\hline & Group ......... & $\mathbf{P b}-\mathbf{Z n}$ \\
\hline 16 & Good Hope Mines.. & $\mathbf{w}$ \\
\hline 17 & Royal Tungsten ... & w \\
\hline 18 & Martin ........... & $\mathbf{w}$ \\
\hline
\end{tabular}

Figure 2.-Map showing Moses and Dennison Peak Roadless Areas, localities with mineral resource potential, and location of mines and prospects. 
